\title{
Infection rate of Eperythrozoon spp. in Chinese population: a systematic review and meta- analysis since the first Chinese case reported in 1991
}

De-Sheng Huang ${ }^{1,2^{*}}$, Peng Guan ${ }^{1}$, Wei Wu' ${ }^{1}$ Tie-Feng Shen ${ }^{3}$, He-Ling Liư ${ }^{4}$, Shuang Cao ${ }^{1}$ and Hao Zhou ${ }^{1}$

\begin{abstract}
Background: Eperythrozoonosis is an important animal health problem worldwide, it not only has a major impact on the economic viability, but also makes a significant impact on public health issues. The present systemic review intends to collate all relevant published data to assess the burden of Eperythrozoon infection in Chinese population and discuss the implications of these findings for public health policy.

Methods: A meta-analysis was conducted to review the published studies that reported Eperythrozoon spp. in Chinese population. Inclusion criteria comprised of the use of microscopic venous blood smear examination for Eperythrozoon detection and a detailed description of sampling techniques.

Results: Twenty-four cross-sectional studies with 52,433 participants and 14,951 positive cases, within the range of China mainland, were included in the present analysis. The infection rate of Eperythrozoon varied from 0 to $97.29 \%$ with geographical and seasonal variations, people with mild infection intensity contributed the major part (68.93\%). The infection rates were highest in the children and adolescents group, significantly increased risk of Eperythrozoon infection was found among herdsmen.

Conclusions: The current study raises awareness about the human eperythrozoonosis in China, which is a newly emerging zoonosis. The majority of Eperythrozoon infection intensity was asymptomatic mild infection. The infection rate of Eperythrozoon in Chinese population varied by geographical region, season, age and occupation. These factors need to be considered when conducting health education campaigns and comparing the surveillance results from different studies.
\end{abstract}

Keywords: Eperythrozoon, Infection, Meta-analysis

\section{Background}

Eperythrozoonosis is an important animal health problem worldwide, more than 30 countries and regions have reported the diseases in at least 14 kinds of host animals in different species of vertebrate, including rodents, ruminants, and pigs [1-5]. It not only has a major impact on the economic viability (e.g. production losses, prevention or treatment costs and etc.), but also makes a

\footnotetext{
* Correspondence: dshuang@mail.cmu.edu.cn

'Department of Epidemiology, School of Public Health, China Medical University, Shenyang 110001, China

${ }^{2}$ Department of Mathematics, College of Basic Medical Sciences, China Medical University, Shenyang 110001, China

Full list of author information is available at the end of the article
}

significant impact on public health issues due to they have been judged to be a zoonosis and also an infectious disease transmissible from animals to humans $[6,7]$.

The first recognized and confirmed human case of eperythrozoonosis was reported in 1986 worldwide [8]. The disease may manifest with fever, hemolytic anemia, swollen lymph nodes of the neck, an enlarged liver and spleen, leucopenia, neutropenia, thrombocytopenia and sometimes acute hemolysis, mild hepatitis and subclinical myocarditis [8-10]. Eperythrozoonosis actually is a microscopic diagnosis, and the causative agent was previously reported as 'Eperythrozoon'. Currently, eperythrozoonosis was replaced by the laboratory diagnosis of 
haemotrophic mycoplasma infection. Haemotrophic mycoplasmas are small, pleomorphic, uncultivable bacteria which parasitise the surface of red blood cells of a wide range of mammalians and can induce erythrocytic deformity and damage [4,11]. Haemotrophic mycoplasmas were originally classified within two genera of the Rickettsiales order, i.e. Eperythrozoon and Haemobartonella. Then, based on strong phylogenetic evidence and $16 \mathrm{~S}$ ribosomal RNA gene sequences, Eperythrozoon and Haemobartonella were reclassified into the group of haemotrophic mycoplasmas within the family of Mycoplasmataceae [11-13].

However, the name of 'Eperythrozoon' and 'Eperythrozoonosis' is still adopted in the present study due to its wide acceptance and the cytology-based diagnosis in China. In China, the first human case was reported in 1991 [14], afterwards approximately 180 human cases have been sporadically reported in 18 provinces, autonomous regions and municipalities. Alongside animal field studies, several surveys have been conducted among Chinese populations to provide epidemiological knowledge of the distribution of eperythrozoon infection with the aim to lay the basis for disease prevention and control strategies [15-18]. Whilst those studies varied in infection diagnosis criteria or other methodological factors and were performed under diverse settings. Thus, different conclusions have been obtained, for example, some reported an increased risk in male, and others failed to confirm this association.

The present systemic review and meta-analysis takes advantages of the recent enrichment in the number of published investigations in China and intends to collate all relevant published data to assess the burden of Eperythrozoon infection in Chinese population and discuss the implications of these findings for public health policy.

\section{Methods}

Identification and eligibity of relevant studies

The literature was systematically reviewed by searching the ISI Web of Knowledge database, PubMed and the database of China National Knowledge Infrastructure (CNKI) for relevant articles without language restriction or publication year with the keywords "Eperythrozoon" (up to September 2011). The references cited in the retrieved publications were also screened to trace further relevant studies. Inclusion criteria comprised of the use of microscopic venous blood smear examination for Eperythrozoon detection (at least one Eperythrozoon per 20 vision fields of the microscope or per 200 erythrocytes), the inclusion of at least 75 people tested and a detailed description of sampling techniques. When studies from the same research group with overlapped population were found, only the one with larger population was included to avoid data duplication.

\section{Data extraction}

Data were independently evaluated and extracted by two investigators (DSH and PG) with all the discrepancies discussed and resolved by consensus. For each included study, information was retrieved regarding publication characteristics (first author, journal name and year of publication); characteristics of participants (age, gender, occupation, number of people tested for Eperythrozoon infection, and number of positive cases), study characteristics (study sample type, period, sample collection method, detection method and criteria of positive diagnosis). The study sample type was classified into two categories, population-based or convenient (mainly including inpatients or outpatients) sample. The data quality of included studies was assessed and statistics were calculated again if applicable, the error corrections were made after enquiries from the authors or group discussion.

\section{Statistical analyses}

The heterogeneity between the studies was evaluated by the Chi square-test based Q-statistic. The crude infection rate was calculated by pooling the number of Eperythrozoon-positive people by the total number of people tested from included studies. All the pooled statistics were calculated using data from population-based surveys. The infection rates were grouped into 3 levels by hierarchical cluster analysis. For age-specific analysis, the infection rate was compared within 4 broad age groups $(\leq 19,20-39,40-59$ and $\geq 60$ years). The seasonal variations of the infection rate were examined within 2 major intervals (Winter \& Spring: December-May; Summer \& Autumn: June-November). Mantel-Haenszel chi-square test was adopted to analyze binomial data and logistic regression was performed for data with three or more categories, then the combined odds ratio was calculated. Due to the geographical variations, the combined odds ratio was adjusted for the area in the age and occupation-specific sub-analysis. The infection intensity was recorded according to Gulland's method for animals [19], less than 30 Eperythrozoon infected in every 100 erythrocytes was classified as mild, between 30 and 60 termed as moderate and more than 60 recorded as the severe infection. Begg's test is used for the detection of publication bias. All analyses were done using SPSS software (SPSS 12.0 for windows, SPSS Inc., Chicago, IL, USA). All the $P$ values were two-sided.

\section{Results}

In total, 140 papers were evaluated from which 24 publications [15-36] were included (see Figure 1 for selection process). Table 1 shows crude Eperythrozoon infection rate in 52,433 people tested, with 14,951 positive individuals. The largest sample consisted of 18,316 tested 


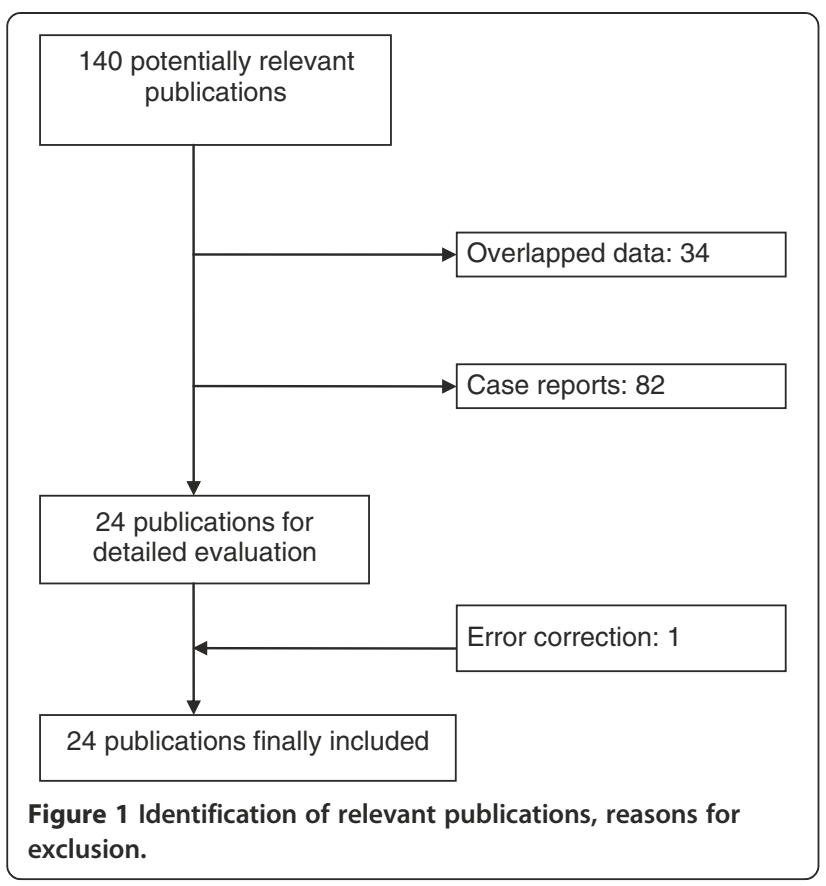

people in Guangdong Province, followed by the study in Hubei Province (5,224 tested people) and in Shandong Province (5,217 tested people) and the study conducted by Chinese National Consortium on Eperythrozoonosis Research (CNCER) ranked $4^{\text {th }}$ from this sample size point of view (4,033 tested people).

Figure 2 shows the available crude Eperythrozoon infection rate among tested populations in different regions of China (using data from population-based surveys), by trisections of infection rate. The highest infection rate was found in farming and pastoral regions. Figure 2 also indicates the geographical heterogeneity of the infection rates, because there were also differences in some part of these regions.

Table 2 shows that there was no difference in the infection rate between the male and female $(41.14 \%$ vs. 42.21\%). Table 2 indicates the Eperythrozoon infection rates for 5 studies with age-specific data. The infection rates were highest in the children and adolescents group (younger than 19 years) and the infection rate decreased in 20-39, 40-59 year-groups, and the older age-groups (more than 60 years). From the 8 studies that provided occupation-specific infection information, there were remarkable differences in different occupations. The highest infection rate with statistical significance was found in herdsmen (Table 2). From the subset of studies with the information about contact history of animals, the infection rate was significant higher in the exposed group than that in the unexposed group (OR, 6.40 with the $95 \% \mathrm{CI} 5.50-7.37)$. In the stratified analysis by nationality, there were only two studies with detail information about the nationality of the tested population, and no statistical differences were found for the Eperythrozoon infection rates.

The seasonal variations of the Eperythrozoon infection rates were evaluated in 2 included studies. The infection rate was significantly higher in summer \& autumn than that in winter \& spring (Table 2). Two studies provided the infection information separated into urban and rural areas, residents in the rural area had higher infection rates compared with residents in urban area, however, the difference was not statistically significant (OR, 2.83 with the 95\%CI 0.36-22.55).

With respect to the route of transmission, there were three studies with interest on the route of vertical transmission, among the total 167 Eperythrozoon-positive mothers, 165 children tested positive for Eperythrozoon.

Table 3 shows the distribution of the Eperythrozoon infection intensity, among the 6,180 Eperythrozoon-positive individuals from 8 studies, people with mild infection intensity contributed the major part (68.93\%), followed by moderate (19.21\%) and severe infection (11.86\%).

\section{Discussion}

In past 20 years, there is increasing concern in human eperythrozoonosis, which is a newly emerging disease in China. Among the 140 publications that we have collected, eighty-two publications were the case reports of human eperythrozoonosis and nine of their titles indicated 'the first case' in their local area. Eperythrozoonosis has a wide spectrum of clinical manifestations, which can vary from subclinical infection to weakness, fever, icterus, anemia, and et al. For the prevention and control of this kind of disease, the infection distribution, related risk factors and possible routes of transmission are necessary. Thus, the published cross-sectional surveys of Eperythrozoon infection rates were summarized to provide a rough estimation of the above information. To our knowledge, this is the first systematic review about the epidemiological data on the infection rate of Eperythrozoon in China nationwide.

Within the range of China mainland, human eperythrozoonosis cases from 18 provinces, autonomous regions and municipalities have been reported, the infection rates varied from 0 to $97.29 \%$ in the 24 included studies, which indicated that several aspects of factors might contribute to the variations. From the geographical point of view, the relatively high infection rate was found in pastoral areas located in the northweast region, the lowest was found in Tibet and the major part of infection was asymptomatic mild infection. The great difference contributed our decision to compare the infection rates stratified by the selected factors after adjusting the geographical location. 
Table 1 Infection rate of human Eperythrozoon in different areas of China

\begin{tabular}{|c|c|c|c|c|c|c|}
\hline & First author, publication year & Province (city or county) & Sample type & $\begin{array}{l}\text { Number of } \\
\text { tested (N) }\end{array}$ & $\begin{array}{l}\text { Number of } \\
\text { positive }(n)\end{array}$ & $\begin{array}{l}\text { Infection } \\
\text { rate (\%) }\end{array}$ \\
\hline \multirow[t]{7}{*}{$1-3$} & \multirow{7}{*}{$\begin{array}{l}\text { Chinese National Consortium } \\
\text { on Eperythrozoonosis Research } \\
\text { (CNCER), 1995,1996 and } 1997 \text { [15-17] }\end{array}$} & Jiangsu & Population-based & 1975 & 1552 & 78.58 \\
\hline & & Hebei & Population-based & 975 & 0 & 0.00 \\
\hline & & Liaoning & Population-based & 124 & 0 & 0.00 \\
\hline & & Ningxia & Population-based & 96 & 16 & 16.67 \\
\hline & & Guangxi & Population-based & 444 & 232 & 52.25 \\
\hline & & Guangdong & Population-based & 219 & 113 & 51.60 \\
\hline & & Xinjiang & Population-based & 200 & 90 & 45.00 \\
\hline \multirow[t]{2}{*}{4} & Liu, 1997 [20] & Gansu & Population-based & 277 & 205 & 74.01 \\
\hline & & & Convenient & 737 & 649 & 88.06 \\
\hline 5 & Tai, 1998 [21] & Inner Mongolia & Population-based & 1529 & 540 & 35.32 \\
\hline \multirow[t]{2}{*}{6} & Huang, 1999 [22] & Yunnan (Yuxi) & Population-based & 1461 & 984 & 67.35 \\
\hline & & & Convenient & 3191 & 2486 & 77.91 \\
\hline \multirow[t]{2}{*}{7} & Dong, 2000 [23] & Fujian & Population-based & 932 & 434 & 46.57 \\
\hline & & & Convenient & 54 & 51 & 94.44 \\
\hline \multirow[t]{2}{*}{8} & Yang, 2000 [24] & Jiangsu & Population-based & 210 & 42 & 20.00 \\
\hline & & & Convenient & 190 & 13 & 6.84 \\
\hline \multirow[t]{2}{*}{9} & Li, $2001[25]$ & Anhui & Population-based & 614 & 174 & 28.34 \\
\hline & & & Convenient & 206 & 98 & 47.57 \\
\hline 10 & Zhao, 2001 [26] & Inner Mongolia & Convenient & 187 & 153 & 81.82 \\
\hline 11 & Tao, 2001 [27] & Shandong & Population-based & 776 & 57 & 7.35 \\
\hline \multirow[t]{2}{*}{12} & Zhang, 2002 [28] & Ningxia & Population-based & 150 & 56 & 37.33 \\
\hline & & & Convenient & 150 & 67 & 44.67 \\
\hline \multirow[t]{2}{*}{13} & Chen, 2003 [29] & Liaoning (Dalian) & Population-based & 887 & 863 & 97.29 \\
\hline & & & Convenient & 164 & 120 & 73.17 \\
\hline \multirow[t]{2}{*}{14} & Zhou, 2003 [30] & Chongqing (Xingshan) & Population-based & 174 & 17 & 9.77 \\
\hline & & & Convenient & 407 & 2 & 0.49 \\
\hline 15 & Shi, 2007 [31] & Tibet & Population-based & 3214 & 103 & 3.20 \\
\hline 16 & Zhou, 2007 [32] & Hubei (Xingshan county) & Population-based & 5224 & 2931 & 56.11 \\
\hline 17 & $\mathrm{He}, 2007$ [33] & Yunnan (Gongshan) & Population-based & 1408 & 960 & 68.18 \\
\hline 18 & Li, 2008 [34] & Shandong (Wendeng) & Population-based & 5217 & 15 & 0.29 \\
\hline 19 & Zhu, 2008 [35] & Shanghai & Population-based & 997 & 129 & 12.94 \\
\hline \multirow[t]{3}{*}{20} & Han, 2009 [36] & Shandong (Taian) & Population-based & 617 & 85 & 13.78 \\
\hline & & & Convenient* & 201 & 64 & 31.84 \\
\hline & & & Convenient & 169 & 74 & 43.79 \\
\hline 21 & Qiu, 2010 [37] & Guangdong (Maoming) & Population-based & 18316 & 1484 & 8.10 \\
\hline 22 & Huang, 2010 [38] & Guangxi (Mengshan) & Convenient & 86 & 15 & 17.44 \\
\hline \multirow[t]{2}{*}{23} & Deng, 2010 [39] & Zhejiang (Hangzhou) & Population-based & 469 & 31 & 6.61 \\
\hline & & & Convenient* & 111 & 23 & 20.72 \\
\hline \multirow[t]{2}{*}{24} & Zhang, 2010 [40] & Liaoning (Huludao) & Population-based & 75 & 23 & 30.67 \\
\hline & & Total & & 52433 & 14951 & 28.51 \\
\hline
\end{tabular}

*Here limited to the butcher, herdsman and veterinarian. 


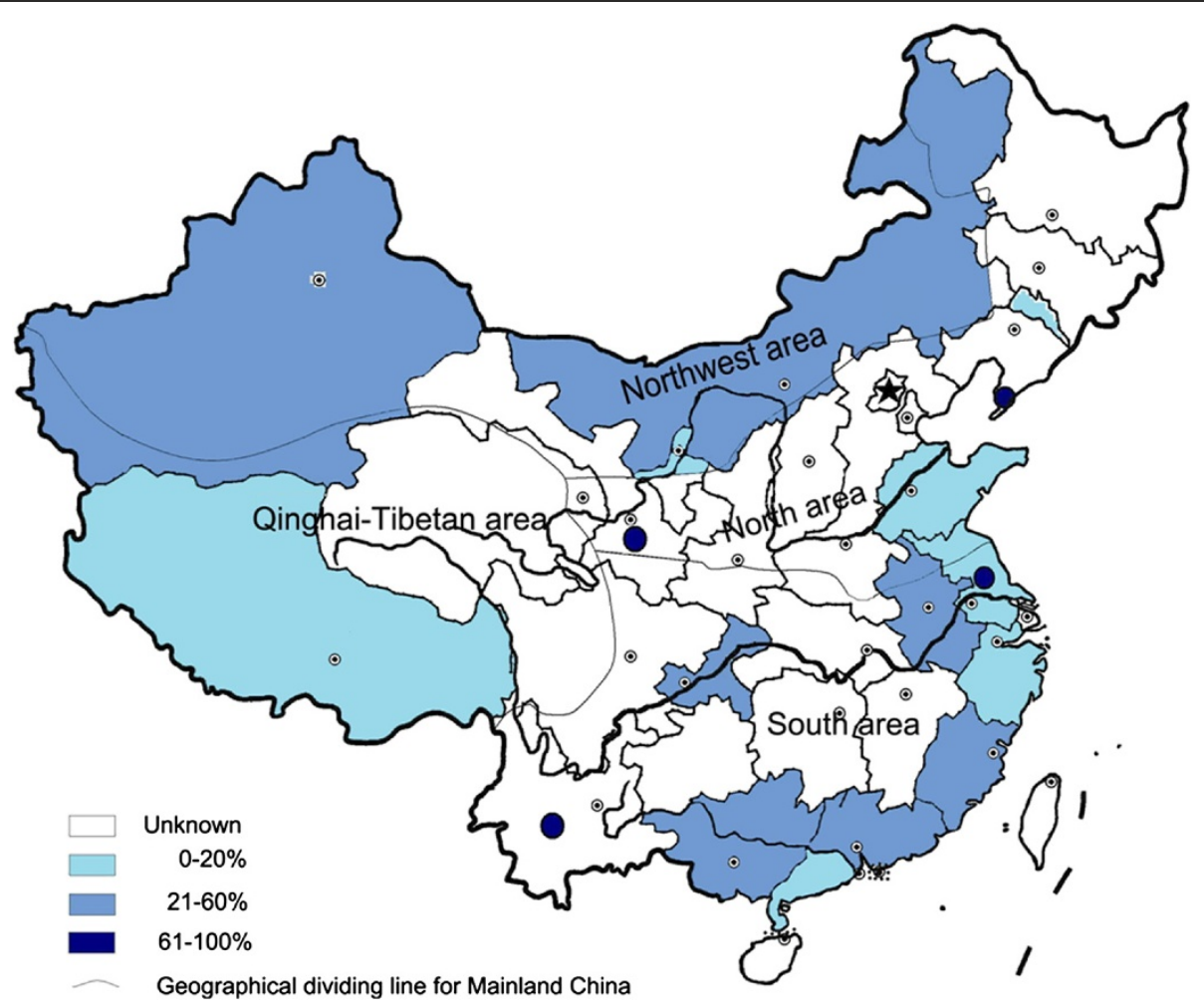

Figure 2 Crude Eperythrozoon infection rate reported by the included population-based studies in mainland China"\#. \# The boundaries used in this map do not imply the expression of any opinion concerning the legal status of any territory, city or area of its authority or concerning the delimitation of its frontiers and boundaries.

It has been reducted from animal experiments that the transmission of eperythrozoonosis could be via the respiratory and gastrointestinal tracts and the vectors such as the mosquitoes were also involved in the eperythrozoonosis transmission [41]. This correspondence is also present in our results, the eperythrozoonosis existed all over the year while with seasonal distribution, which might due to seasonal exposure possibilities and densities of insect vectors.

As for the association between population characteristics and Eperythrozoon infection rate, our results are in partial concordance with the results from Chinese $\mathrm{Na}$ tional Consortium on Eperythrozoonosis Research published in 1997 [17]. They indicated that the state of human body had the effect on the Eperythrozoon infection and no association between the gender and the infection rate was observed. The national survey showed that the infection rate was highest among the children and adolescents group and among the milking workers and doctors, nevertheless, the differences were not statistically significant, which is different from our results. This may due to that more people were analyzed in the present review and the selection bias might be reduced by including the people from broader geographical range. In the age-specific subanalysis, the highest infection rate was found in the children group, and in some studies, the second peak in older people was also observed, the pattern may attribute to their unmature or weak immune function. The results may also help the clinicians or pediatricians to keep the Eperythrozoon infection in mind, especially in the high-risk area. The occupational variations of infection rates could be attributed to the different exposure possibilities and extent. Those variations of Eperythrozoon infection rates in geographical location, age-group and occupation can have significant implications for the design and effectiveness of prevention and control strategies.

Among the collected publications, familial aggregation was reported by 3 individual studies, which suggested that the environmental factors or life style factors might be involved in the Eperythrozoon infection. Contact with livestock, or poultry and international travel have been reported as risk factors among those case report publications $[9,10,42]$. According to the available Eperythrozoon infection information in pigs or diary cows, multiple infection of different pathogens existed in eperythrozoonosis, which posed more threats for the farmers, herdsmen or milking workers. It has been summarized that Mycoplasma suis (formerly known as Eperythrozoon suis) can cause acute disease, but the major significance of M. suis 
Table 2 Overall Eperythrozoon infection rate by selected variables

\begin{tabular}{|c|c|c|c|c|c|c|c|c|c|}
\hline Variable & & $\begin{array}{l}\text { Number of } \\
\text { countributing } \\
\text { studies }\end{array}$ & $\begin{array}{l}\text { Total } \\
\text { tested }\end{array}$ & $\begin{array}{l}\text { Eperythrozoon } \\
\text { positive }\end{array}$ & $\begin{array}{l}\text { Crude } \\
\text { infection } \\
\text { rate }(95 \% \mathrm{Cl})\end{array}$ & $\begin{array}{l}\text { OR/Adjusted } \\
\text { OR by area } \\
(95 \% \mathrm{Cl})\end{array}$ & $\begin{array}{l}\text { Heterogeneity } \\
\text { chi-square }\end{array}$ & $\begin{array}{l}P \\
\text { value }\end{array}$ & $\begin{array}{l}\text { Publication } \\
\text { bias }\end{array}$ \\
\hline \multirow[t]{4}{*}{ Gender } & \multirow[t]{2}{*}{ Male } & \multirow[t]{2}{*}{8} & \multirow[t]{2}{*}{7129} & \multirow[t]{2}{*}{2933} & 41.14 & \multirow[t]{2}{*}{ Ref. } & \multirow[t]{2}{*}{-} & \multirow[t]{2}{*}{ - } & \multirow[t]{4}{*}{ None } \\
\hline & & & & & $(40.00-42.28)$ & & & & \\
\hline & \multirow[t]{2}{*}{ Female } & \multirow[t]{2}{*}{8} & \multirow[t]{2}{*}{7408} & \multirow[t]{2}{*}{3127} & 42.21 & 1.03 & \multirow[t]{2}{*}{26.02} & \multirow[t]{2}{*}{$<0.01$} & \\
\hline & & & & & $(41.09-43.33)$ & $(0.86-1.24)$ & & & \\
\hline \multirow{10}{*}{$\begin{array}{l}\text { Age of enrolled } \\
\text { population (yrs) }\end{array}$} & \multirow[t]{2}{*}{$\leq 19$} & \multirow[t]{2}{*}{4} & \multirow[t]{2}{*}{1771} & \multirow[t]{2}{*}{1342} & 75.78 & Ref. & \multirow[t]{2}{*}{-} & \multirow[t]{2}{*}{-} & \multirow[t]{10}{*}{ t } \\
\hline & & & & & $(73.78-77.77)$ & & & & \\
\hline & \multirow[t]{2}{*}{$20-39$} & \multirow[t]{2}{*}{5} & \multirow[t]{2}{*}{9288} & 1738 & 18.71 & 0.55 & $67.52^{\#}$ & $<0.01$ & \\
\hline & & & & & $(17.92-19.51)$ & $(0.48-0.64)$ & & & \\
\hline & $40-59$ & 5 & 9330 & 1310 & 14.04 & 0.59 & $47.20^{\#}$ & $<0.01$ & \\
\hline & & & & & $(13.34-14.75)$ & $(0.50-0.68)$ & & & \\
\hline & $\geq 60$ & 5 & 3459 & 411 & 11.88 & 0.80 & $5.80^{\#}$ & 0.02 & \\
\hline & & & & & $(10.80-12.96)$ & $(0.67-0.96)$ & & & \\
\hline & Age & & & & & & $94.47^{\#}$ & $<0.01$ & \\
\hline & Area & & & & & & $3980.23^{\#}$ & $<0.01$ & \\
\hline Occupation & Employees & 2 & 413 & 212 & 51.33 & Ref. & - & - & $\dagger$ \\
\hline & $\begin{array}{l}\text { with the food } \\
\text { industry } \\
\text { exceptional }\end{array}$ & & & & $(46.51-56.15)$ & & & & \\
\hline & Employees & 3 & 1458 & 832 & 57.06 & 0.85 & $1.45^{\#}$ & 0.23 & \\
\hline & $\begin{array}{l}\text { In the food } \\
\text { industry }\end{array}$ & & & & $(54.52-59.60)$ & $(0.66-1.10)$ & & & \\
\hline & Farmers & 4 & 1551 & 754 & 48.61 & 1.98 & $4.78^{\#}$ & 0.03 & \\
\hline & & & & & $(46.12-51.10)$ & $(1.07-3.64)$ & & & \\
\hline & Herdsmen & 6 & 530 & 296 & 55.85 & 3.65 & $27.34^{\#}$ & $<0.01$ & \\
\hline & & & & & $(51.62-60.08)$ & $(2.25-5.93)$ & & & \\
\hline & Occupation & & & & & & $44.75^{\#}$ & $<0.01$ & \\
\hline & Area & & & & & & $641.56^{\#}$ & $<0.01$ & \\
\hline Contact history & No & 3 & 5548 & 575 & 10.36 & Ref. & - & - & None \\
\hline & & & & & $(9.56-11.17)$ & & & & \\
\hline & Yes & 3 & 1413 & 808 & 57.18 & 6.40 & 233.38 & $<0.01$ & \\
\hline & & & & & $(54.60-59.76)$ & $(5.50-7.37)$ & & & \\
\hline Season & $\begin{array}{l}\text { Winter \& } \\
\text { Spring }\end{array}$ & 2 & 9127 & 460 & 5.04 & Ref. & & & $\dagger$ \\
\hline & & & & & $(4.59-5.49)$ & & & & \\
\hline & $\begin{array}{l}\text { Summer \& } \\
\text { Autumn }\end{array}$ & 2 & 10178 & 1564 & 15.37 & 4.26 & 6.91 & $<0.01$ & \\
\hline & & & & & $(14.67-16.07)$ & $(3.01-6.02)$ & & & \\
\hline Location & Urban area & 2 & 839 & 633 & 75.45 & Ref. & - & - & $\dagger$ \\
\hline & & & & & $(72.54-78.36)$ & & & & \\
\hline & Rural area & 2 & 1456 & 1190 & $\begin{array}{l}81.73 \\
(79.75-83.71)\end{array}$ & $\begin{array}{l}2.83 \\
(0.36-22.55)\end{array}$ & 21.86 & $<0.01$ & \\
\hline
\end{tabular}

\# Wald Chi-square; † Unable to evaluate.

infections lies in the fact that M. suis can establish chronic and persistent infections leading to a higher susceptibility to other infections, especially of the respiratory and digestive tracts [43].
Our study has several limitations. The major limitation is that in the included studies, the diagnostic method used to define Eperythrozoon infection is based on microscopy. The microscopic detection of the agent in 
Table 3 Distribution of Eperythrozoon infection intensity

\begin{tabular}{|c|c|c|c|c|c|}
\hline Study & & Number of positive & Mild & Moderate & Severe \\
\hline Tai, 1998 [21] & & 540 & 484 & 43 & 13 \\
\hline Zhao, 2001 [26] & & 153 & 98 & 39 & 16 \\
\hline Tao, 2001 [27] & & 57 & 44 & 11 & 2 \\
\hline Chen, 2003 [29] & & 866 & 367 & 157 & 342 \\
\hline \multirow[t]{2}{*}{ Zhou, 2007 [32] } & Male & 1295 & 963 & 240 & 92 \\
\hline & Female & 1636 & 1229 & 304 & 103 \\
\hline Zhu, 2008 [35] & & 129 & 129 & 0 & 0 \\
\hline \multirow[t]{2}{*}{ Qiu, 2010 [37] } & Symptomatic group & 178 & 66 & 73 & 39 \\
\hline & Asymptomatic group & 1301 & 855 & 320 & 126 \\
\hline Deng, 2010 [39] & & 25 & 25 & 0 & 0 \\
\hline Total (proportion) & & $6180(100 \%)$ & $4260(68.93 \%)$ & 1187 (19.21\%) & $733(11.86 \%)$ \\
\hline
\end{tabular}

blood smears is limited by its low sensitivity and specificity. $[11,44,45]$. It is difficult to differentiate Eperythrozoon from haemobartonella $[11,46]$, there are reports on human haemotrophic mycoplasmas that seem to be bacteria which would be formerly classified as haemobartonella [9], thus all the reviewed articles might have suffered from misclassification bias. The second limitation or difficulty in the present systematic review is to deal with the heterogeneity of the included studies, in which the definition of Eperythrozoon infection, the sampling method and the representative of the population varied slightly from one to another. To accommodate the heterogeneity, only those studies using blood smearbased method and with detailed description of sampling techniques were included. The geographical distribution of the included tested population differed from the realworld distribution of population, thus it is difficult to derive the whole estimates of the Eperythrozoon infection rate in China by accounting for variation in study design and detection assays used. Third, we looked at a limited number of available variables and could not look at some factors such as socioeconomic factors and heath behaviours.

\section{Conclusions}

In summary, the current study raises awareness about the human eperythrozoonosis in China, which is a newly emerging zoonosis. The majority of Eperythrozoon infection intensity was asymptomatic mild infection. The infection rate of Eperythrozoon in Chinese population varied by geographical region, season, age and occupation. These factors need to be considered when conducting health education campaigns and comparing the surveillance results from different studies.

\section{Competing interests}

The authors declare that they have no competing interests.

\section{Authors' contributions}

DSH provided overall leadership to the study, secured funding and conducted the data collection and analysis. PG contributed to the data collection, data analysis and drafted the manuscript. WW, TFS, HLL, SC and $\mathrm{HZ}$ have been involved in the data collection, data check, data analysis and discussion. All authors contributed to the study design and participated in writing the paper. All authors have read and approved the final manuscript.

\section{Acknowledgements}

This work was supported by the National Natural Science Foundation of China (NNSFC), No. 71073175. The funding source had no role in the study design, data collection, analysis and interpretation, or in the writing of this manuscript.

\section{Author details}

${ }^{1}$ Department of Epidemiology, School of Public Health, China Medical University, Shenyang 110001, China. ${ }^{2}$ Department of Mathematics, College of Basic Medical Sciences, China Medical University, Shenyang 110001, China. ${ }^{3}$ Huludao Municipal Center for Disease Control and Prevention, Huludao 125000, China. ${ }^{4}$ Department of Biomedical Engineering, China Medical University, Shenyang 110001, China.

Received: 02 February 2012 Accepted: 16 July 2012

Published: 31 July 2012

\section{References}

1. Berkenkamp SD, Wescott RB: Arthropod transmission of Eperythrozoon coccoides in mice. Lab Animal Sci 1988, 38:398-401.

2. Hoff B, Hood D, McCaig L, Moore A: Eperythrozoonosis in sheep. Can Vet J 1996, 37:747-748.

3. Guimaraes AM, Biondo AW, Lara AC, Messick JB: Exploratory study of Mycoplasma suis (Eperythrozoon suis) on four commercial pig farms in southern Brazil. Vet Rec 2007, 160:50-53.

4. Messick JB: Hemotrophic mycoplasmas (hemoplasmas): a review and new insights into pathogenic potential. Vet Clin Pathol 2004, 33:2-13.

5. Wu J, Yu J, Song C, Sun S, Wang Z: Porcine eperythrozoonosis in China. Ann N Y Acad Sci 2006, 1081:280-285.

6. Nikol'skiI SN, Slipchenko SN: Experiments in the transmission of Eperythrozoon ovis by the ticks H. plumbeum and Rh. bursa. Veterinariia 1969, 5:46. in Russian.

7. Braverman Y: Nematocera (Ceratopogonidae, Psychodidae, Simuliidae and Culicidae) and control methods. Revue Scienti Techn 1994, 13:1175-1199.

8. Puntaric V, Borcić D, Vukelić D, Jeren T, Burek V, Wikerhauser T, Richter B: Eperythrozoonosis in man. Lancet 1986, 2:868-869.

9. Steer JA, Tasker S, Barker EN, Jensen J, Mitchell J, Stocki T, Chalker VJ, Hamon M: A novel hemotropic Mycoplasma (hemoplasma) in a patient with hemolytic anemia and pyrexia. Clin Infect Dis 2011, 53:e147-151.

10. Bosnic D, Baresic M, Anic B, Sentic M, Cerovec M, Mayer M, Cikes N: Rare zoonosis (hemotrophic mycoplasma infection) in a newly diagnosed 
systemic lupus erythematosus patient followed by a Nocardia asteroides pneumonia. Braz J Infect Dis 2010, 14:92-95.

11. Hoelzle LE: Haemotrophic mycoplasmas: recent advances in Mycoplasma suis. Vet Microbiol 2008, 130:215-226.

12. Messick JB, Berent LM, Cooper SK, Messick JB, Berent LM, Cooper SK: Development and evaluation of a PCR-based assay for detection of Haemobartonella felis in cats and differentiation of $\mathrm{H}$. felis from related bacteria by restriction fragment length polymorphism analysis. J Clin Microbiol 1998, 36:462-466

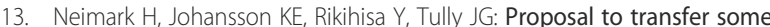
members of the genera Haemobartonella and Eperythrozoon to the genus Mycoplasma with descriptions of 'Candidatus Mycoplasma haemofelis', 'Candidatus Mycoplasma haemomuris', 'Candidatus Mycoplasma haemosuis' and 'Candidatus Mycoplasma wenyonii'. Int J Syst Evol Microbiol 2001, 51:891-899.

14. Tai XZ, Yang DX: Human eperythrozoonosis. Chin Inner Mong Med J 1991, 11:122. in Chinese

15. Shang DQ, Li LY, Luan JH, Wang SY, Zhang JZ, Liu FC, Zhang RY, Li CY, Cao L, Zhao ZL, Tang WY, Jiang AG, Wang YH, Li GX, Zhang FS, Wang KJ, Ma XH, Jia ZL, Zhang YQ, Pei B, Xu YC: An epidemiological investigation of eperythrozoon infection in human and animals. A Collaborative Research Group on Eperythrozoonosis. Zhonghua Liu Xing Bing Xue Za Zhi 1995, 16:143-146. in Chinese.

16. Shang DQ, Li LY, Pei B, Wang SY, Liu RH, Zhao HY, Sun GJ, Tang HZ, Tang AW, Zhang JZ, Sun ET, Liu ZC, Liu G, Yang DD, Liu FC, An HZ, Liang Q, Li JG: An epidemiological investigation of eperythrozoon infection in human and animals (II). Zhonghua Liu Xing Bing Xue Za Zhi 1996, 17:221-224. in Chinese.

17. Shang DQ, Li YL, Lu ZG, Pei B, Yan JH, Li MR, Xue ZQ, Lin CM, Gao J, Zhang LH, Xin SK, Liu YE, Liu YZ, Gao WH, Tao MK, Yan YQ, Cheng HF, Chai SZ, Yang H, Zhang JC, Wang DF, Qi J: An epidemiological investigation of eperythrozoon infection in human and animals (III). Zhonghua Liu Xing Bing Xue Za Zhi 1997, 18:150-152. in Chinese.

18. Yang D, Tai X, Qiu Y, Yun S: Prevalence of Eperythrozoon spp. infection and congenital eperythrozoonosis in humans in Inner Mongolia, China. Epidemiol Infect 2000, 125:421-426.

19. Gulland FW, Doxey DL, Scott GR: Changing morphology of Eperythrozoon ovis. Res Vet Sci 1987, 43:88-91.

20. Liu XF, Tian H, Hou SL, Sun ZX, Zang RX, Li QJ, Zhao WP, Yang WH: Survey of eperythrozoon infection in human and animals and the route of transmission. Zhongguo Shou Yi Za Zhi 1997, 23:23-24. in Chinese.

21. Tai $X Z$, Yang DX, Qin LJ, Yang HP, Jin LP, Qi GL, Yun X: Investigation and analysis of eperythrozoon infection in human in Inner Mongolia. Zhongguo Ren Shou Gong Huan Bing Za Zhi 1998, 14:90-91. in Chinese.

22. Huang ZM, Ma XW, Huang JM, Zhao W, Gong JY, Wang KW: An epidemiological investigation of eperythrozoon infection in human in Yuxi, Yunnan. Zhongguo Gong Gong Wei Sheng 1999, 15:31. in Chinese.

23. Dong CZ, Yan WY, Liu CC, Wei XJ, Huang RL: An epidemiological investigation of eperythrozoon infection in human in Sha County. Zhonghua Yu Fang Yi Xue Za Zhi 2000, 34:158. in Chinese.

24. Yang $X C$, Zhang ZC, Sui $Y$ : An epidemiological investigation of eperythrozoon infection in human in Xuzhou. Yu Fang Yi Xue Wen Xian Xin Xi 2000, 6:39. in Chinese.

25. Li ZY, Wang ZH, Yang YZ, Guo L, Li GL, Liu XQ: Survey of eperythrozoon infection in human and animals in Fuyang. Zhongguo Gong Gong Wei Sheng 2001, 17:46. in Chinese.

26. Zhao LY, Bai JW: Characteristics of eperythrozoon in human under the electron microscope and clinical manifestation. Neimenggu Yi Xue Za Zhi 2001, 33:108-111. in Chinese.

27. Tao XR, Wang XJ, Sun T, Cui S, Zheng DM, Li Z, Feng KJ, Hu B, Su JY: An epidemic investigation of eperythrozoonsis in Shandong province. Zhonghua Liu Xing Bing Xue Za Zhi 2001, 22:359-361. in Chinese.

28. Zhang MJ, Ling XJ, Feng YM: Analysis of eperythrozoon infection in residents and outpatients in Yinchuan. Ningxia Yi Xue Yuan Xue Bao 2002, 24:60-61. in Chinese.

29. Chen FY, Zhang F, Yao W, Yuan Y, Yang SH, Wang BR, Hu B, Wnag YH, Cui Y, Zheng LL, Li GY, Jin FJ: Survey of eperythrozoon infection in human in Dalian. Zhongguo Ren Shou Gong Huan Bing Za Zhi 2003, 19:100,132. in Chinese.

30. Zhou XC, He GR, Zou DR, Huang XZ, Wang DJ, Wen ZY, Wang CQ, Wu M: Investigation of eperythrozoon infection in the Xingshan part of the
Three Goarges Reservoir areas. Zhongguo Ji Sheng Chong Bing Fang Zhi Za Zhi 2003, 16:19. in Chinese.

31. Shi QG, Li SZ, Yang G, Chen HZ, Lu YZ, Qi BB, Hong Y: The infection and prevention of eperythrozoon in altiplano. Xizang Yi Yao Za Zhi 2007, 28:3-6. in Chinese.

32. Zhou XC, Wang CQ, Wang DJ, Pan HM, Zou XL, Huang XZ, Wu KQ, Xu ZS, He GR, Zheng L: An epidemiological investigation of eperythrozoonsis in Xingshan county of the Three Goarges Reservoir areas. Zhongguo Mei Jie Sheng Wu Xue Ji Kong Zhi Za Zhi 2007, 18:234-237. in Chinese.

33. He CT, Feng YS, Li YL, Zhao J, Chen YX: An epidemiological investigation of eperythrozoon infection in human in Gongshan, Yunnan. Shi Yong Yu Fang Yi Xue 2007, 14:382-383. in Chinese.

34. Li FX, Wang HR, Deng XC: An epidemiological investigation of eperythrozoon infection in human in Wendeng. Zhongguo Cheng Xiang Qi Ye Wei Sheng 2008, 2:58. in Chinese.

35. Zhu M, Cai L, Wang LY, Wang ZY, Shen L, Cai FZ, Fei SJ: Factors analysis of human Eperythtozoon infection in Shanghai. Zhongguo Bing Yuan Sheng Wu Xue Za Zhi 2008, 3:499-501. in Chinese.

36. Han ZQ, Zhao XH, Yu AL, Li D, Li XM: An epidemiological investigation of eperythrozoon infection in human in Taian. Zhongguo Ren Shou Gong Huan Bing Xue Bao 2009, 25:93-94. in Chinese.

37. Qiu ZW, Liu YK, Qiu XQ, Su MJ, Zhao JY: An analysis of eperythrozoon detection results in 18316 petrochemical workers and staff members in Maoming. Baotou Yi Xue Yuan Xue Bao 2010, 26:16-17. in Chinese.

38. Huang YX: Preliminary investigation of eperythrozoon infection in human and animals. Xu Qin Ye 2010, 10:58-59. in Chinese.

39. Deng J, Yang $X H$, Wang $H$ : A survey on eperythrozoon infection in the population from Hangzhou city, Zhejiang province. Zhonghua Liu Xing Bing Xue Za Zhi 2010, 31:647-649. in Chinese.

40. Zhang Y, Zhang ZL, Yin JY, LV J, Dong XC, Shen TF, Li D: An investigation of eperythrozoon infection in a village, Liaoning province. Zhonghua Liu Xing Bing Xue Za Zhi 2010, 31:831-833. in Chinese.

41. Wang Y, Wang ZY, Liu JZ, Yan ZG, Li YJ, Zhang D, Qin XL, Yang DB, Niu XD Ma J, Wang YT: Study on the spread approach in eperythrozoonosis of dairy cow. Zhonghua Liu Xing Bing Xue Za Zhi 2007, 28:311-312. in Chinese.

42. Yuan $C L$, Liang $A B$, Yao CB, Yang ZB, Zhu JG, Cui L, Yu F, Zhu NY, Yang XW, Hua XG: Prevalence of Mycoplasma suis (Eperythrozoon suis) infection in swine and swine-farm workers in Shanghai, China. Am J Vet Res 2009, 70:890-894.

43. Hoelzle LE, Felder KM, Hoelzle K: Porcine eperythrozoonosis: from Eperythrozoon suis to Mycoplasma suis. Tierarztl Prax Ausg G Grosstiere Nutztiere 2011, 39:215-220. in German.

44. Hoelzle LE, Helbling M, Hoelzle K, Ritzmann M, Heinritzi K, Wittenbrink MM: First LightCycler real-time PCR assay for the quantitative detection of Mycoplasma suis in clinical samples. J Microbiol Methods 2007, 70:346-354.

45. Tasker S, Peters IR, Mumford AD, Day MJ, Gruffydd-Jones TJ, Day S, Pretorius AM, Birtles RJ, Helps CR, Neimark H: Investigation of human haemotropic Mycoplasma infections using a novel generic haemoplasma QPCR assay on blood samples and blood smears. J Med Microbiol 2010, 59:1285-1292.

46. Barker EN, Darby AC, Helps CR, Peters IR, Heesom KJ, Arthur CJ, Crossett B, Hughes MA, Radford AD, Tasker S: Molecular characterization of the uncultivatable hemotropic bacterium Mycoplasma haemofelis. Vet Res 2011, 42:83.

doi:10.1186/1471-2334-12-171

Cite this article as: Huang et al:: Infection rate of Eperythrozoon spp. in Chinese population: a systematic review and meta-analysis since the first Chinese case reported in 1991. BMC Infectious Diseases 2012 12:171. 